\title{
EFFECT OF ETOMIDATE ON INTRA-OCULAR PRESSURE
}

\author{
C.E. Famewo, C.O. Odugbesan, and O.O. Osuntokun
}

ETomidate is a new short-acting non-barbiturate hypnotic for the intravenous induction of general anaesthesia. It is water soluble with a $\mathrm{pH}$ of 3.9. It is provided as the sulphate, a white powder which is dissolved just prior to use. It is metabolized in the liver and blood by hydrolysis of its ester. Some clinical studies have been reported on various aspects of this drug but none on its influence on intra-ocular pressure.

It is important to know the effect of an anaesthetic drug on intra-ocular pressure for a variety of reasons. First, if the anaesthetic agent does not affect the intraocular pressure, then it will be ideal for tonometry under general anaesthesia, which may be indicated in children and other uncooperative patients. Secondly, if the anaesthetic significantly reduces intra-ocular pressure it will be useful in reducing or preventing suxamethonium-induced increase in intra-ocular pressure; this may be especially important in patients with open-eye trauma. Thirdly, if the anaesthetic increases the intra-ocular pressure, then such an anaesthetic would be contraindicated in patients with ocular laceration.

This paper presents our findings about the effect of etomidate on intra-ocular pressure and compares it with anaesthetic agents previously investigated.

\section{METHOD}

A total of 40 patients were studied in this series. Thirty patients were undergoing minor surgical procedures while ten patients were attending the outpatient ophthalmology clinic. Fifteen patients were premedicated with intramuscular injection of atropine and meperidine about one hour before induction, while the remaining 25 patients received only atropine intravenously at the time of induction. Anaesthesia was induced with etomidate $0.3 \mathrm{mg} / \mathrm{kg}$ body weight given intravenously.

\section{Tonometry}

The eyes were anaesthetized topically with amethocaine 1 per cent and a Schiotz tonometer with $5.5 \mathrm{gm}$ weight was used to measure intra-ocular pressure. The readings obtained were converted to $\mathrm{mm} \mathrm{Hg}$ by using a standard nomogram. Tonometry examinations were made before etomidate as well as one minute and three minutes after etomidate injection. No other anaesthetic agents were used throughout the measurement period. The tonometry readings were taken at these

C.E. Famewo, M.B., B.S., Dip. Anaes,, F.R.C.P.(C), C.O. Odugbesan, M.D., Dip. Anaes., F.R.C.P.(C), Department of Anaesthesia, University College Hospital, Ibadan, Nigeria. O.O. Osuntokun, M.B., B.S., D.O., F.M.C.S.(Ophth.), Department of Ophthalmology, University College Hospital, Ibadan, Nigeria. 
TABLE I

Intra-oculak Pressure Readings ( $\mathrm{mm} \mathrm{Hg}$ )

\begin{tabular}{|c|c|c|c|}
\hline \multirow{2}{*}{$\begin{array}{c}\text { Patient } \\
\text { no. }\end{array}$} & \multirow{2}{*}{$\begin{array}{l}\text { Pre-etomidate } \\
\text { readings }(\mathrm{mm} \mathrm{Hg})\end{array}$} & \multicolumn{2}{|c|}{$\begin{array}{l}\text { Post-etomidate } \\
\text { readings }(\mathrm{mm} \mathrm{Hg})\end{array}$} \\
\hline & & 1 minute & 3 minutes \\
\hline 1 & 13 & 10 & 10 \\
\hline 2 & 16 & 10 & 10 \\
\hline 3 & 8.5 & 4 & 4 \\
\hline 4 & 10 & 4 & 4 \\
\hline 5 & 14.6 & 8.5 & 8.5 \\
\hline 6 & 14.6 & 7.1 & 7.1 \\
\hline 7 & 16.5 & 9.5 & 8.5 \\
\hline 8 & 16.5 & 9.5 & 8.5 \\
\hline 9 & 20 & 10 & 12 \\
\hline 10 & 20 & 10 & 12 \\
\hline 11 & 13 & 10 & 8.5 \\
\hline 12 & 16 & 10 & 10 \\
\hline 13 & 16 & 10 & 12 \\
\hline 14 & 16 & 10 & 10 \\
\hline 15 & 13 & 12 & 10 \\
\hline 16 & 13 & 10 & 10 \\
\hline 17 & 16 & 10 & 12 \\
\hline 18 & 12 & 10 & 10 \\
\hline 19 & 18 & 18 & 18 \\
\hline 20 & 16 & 16 & 16 \\
\hline 21 & 29 & 25.8 & 25.8 \\
\hline 22 & 14 & 12.2 & 10.9 \\
\hline 23 & 14.6 & 10.2 & 8.5 \\
\hline 24 & 12.2 & 10.2 & 8.5 \\
\hline 25 & 18 & 16 & 16 \\
\hline 26 & 18 & 16 & 18 \\
\hline 27 & 10.2 & 8.5 & 8.5 \\
\hline 28 & 15.9 & 14.6 & 10.2 \\
\hline 29 & 10.2 & 4.9 & 4.9 \\
\hline 30 & 20.6 & 10.2 & 10.2 \\
\hline 31 & 12.2 & 10.2 & 10.2 \\
\hline 32 & 10.2 & 7.1 & 7.1 \\
\hline 33 & 14.6 & 12.2 & 12.2 \\
\hline 34 & 13.4 & 10.2 & 10.2 \\
\hline 35 & 14.6 & 10.2 & 10.2 \\
\hline 36 & 20.6 & 10.2 & 10.2 \\
\hline 37 & 14.6 & 8.5 & 8.5 \\
\hline 38 & 27.2 & 12 & 12 \\
\hline 39 & 14.6 & 7.1 & 7.1 \\
\hline 40 & 17.3 & 10.2 & 10.2 \\
\hline mean & 15.52 & 10.62 & 10.51 \\
\hline S.D. & 4.18 & 3.94 & 3.94 \\
\hline
\end{tabular}

times because they correspond respectively to the peak effects of injected suxamethonium and tracheal intubation when these are used on the patients.

\section{Results}

Etomidate caused a general reduction of intra-ocular pressure as shown in Table I. The mean intra-ocular pressure was $10.62 \mathrm{~mm} \mathrm{Hg}$ at one minute and 
TABLE II

Mean Intra-ocular Pressures ( $\mathrm{mm} \mathrm{Hg}$ ) with Different Anaesthetic Agents

\begin{tabular}{|c|c|c|c|c|}
\hline Anaesthetic agents & $\begin{array}{c}\text { Pre- } \\
\text { induction }\end{array}$ & $\begin{array}{c}\text { Post- } \\
\text { induction }\end{array}$ & $\begin{array}{l}\text { Difference } \\
\text { in mean } \\
\text { pressure }\end{array}$ & References \\
\hline Etomidate & $15.52 \pm 4.18$ & $10.51 \pm 3.94$ & -5.1 & Present study \\
\hline $\begin{array}{l}\text { Thiopentone } \\
\text { Diethyl ether } \\
\text { Cyclopropane }\end{array}$ & $\begin{array}{l}17.7 \pm 2.72 \\
17.7 \pm 2.72 \\
17.7 \pm 2.72\end{array}$ & $\begin{array}{r}10.7 \pm 2.23 \\
12 \pm 2.14 \\
11.4 \pm 3.64\end{array}$ & $\begin{array}{l}-7.0 \\
-5.7 \\
-6.3\end{array}$ & $\begin{array}{l}\text { Kornblueth, W., et al. } \\
\quad(1959) \\
\text { (Ref. No. 3) }\end{array}$ \\
\hline $\begin{array}{l}\text { Halothane } \\
\text { Chloroform }\end{array}$ & $\begin{array}{l}18.24 \pm 3.23 \\
19.46 \pm 4.11\end{array}$ & $\begin{array}{l}11.84 \pm 2.43 \\
11.43 \pm 2.88\end{array}$ & $\begin{array}{l}-6.4 \\
-8.0\end{array}$ & $\begin{array}{l}\text { Magora, F. and Collins } \\
\text { V. Z. (1962) } \\
\text { (Ref. No. 5) }\end{array}$ \\
\hline $\begin{array}{l}\text { Innovar } \\
\text { Methoxyflurane }\end{array}$ & $\begin{array}{l}16.16 \pm 2.84 \\
17.41 \pm 1.81\end{array}$ & $\begin{array}{l}14.1 \pm 2.9 \\
11.09 \pm 1.1\end{array}$ & $\begin{array}{l}-2.06 \\
-6.32\end{array}$ & $\begin{array}{l}\text { Ivankovic, A. D. and } \\
\text { Lower, H. J. (1969) } \\
\text { (Ref. No. 6) }\end{array}$ \\
\hline Trilene & $14.25 \pm 2.76$ & $17.75 \pm 2.82$ & +3.5 & $\begin{array}{l}\text { Al-Abrak, M. H. and } \\
\text { Samuel, J. R. (1975) } \\
\text { (Ref. No. 8) }\end{array}$ \\
\hline
\end{tabular}

10.51 at three minutes after etomidate injection. Both means are significantly lower than the baseline (pre-etomidate) mean of $15.52(\mathrm{p}<0.001)$.

The patients maintained satisfactory spontaneous ventilation and relatively unchanged blood pressure during the measurement period. Fourteen patients (35 per cent) developed mild myoclonic movements following etomidate injection. These were self-limiting and had subsided before the one minute measurements of intra-ocular pressure were made. Verbal contact was usually established with the patients within five minutes of etomidate injection. The absence of hangover was desirable in these patients, especially in those attending the outpatient ophthalmology clinic. Some of these were able to walk unsupported within 15 minutes of injection of etomidate.

\section{Discussion}

Etomidate is currently undergoing clinical trials in many centres. Some of the observed advantages of this new non-barbiturate drug include the relative stability of the cardiovascular and respiratory systems. ${ }^{1,2}$ It is pertinent to determine whether this stability also applies to the intra-ocular pressure. Our results have shown consistent decrease in intra-ocular pressure following etomidate administration.

The fall in intra-ocular pressure following etomidate administration was to some extent unexpected in view of the associated myoclonic movements and the lack of systemic hypotension. Among anaesthetic agents previously investigated, thiopentone, ${ }^{3,4}$ di-ethyl ether, ${ }^{3}$ cyclopropane, ${ }^{3}$ halothane, ${ }^{5}$, chloroform, methoxyflurane ${ }^{6}$ and neuroleptanaesthesia ${ }^{6}$ have been shown to decrease intra-ocular pressure. On the other hand, ketamine ${ }^{7}$ and trilene ${ }^{8}$ were shown to increase intraocular pressure (See Table II).

In general, an increase in the intra-ocular pressure can be obtained through one or more of the following mechanisms: 
(a) Increased aqueous humour due to increased production or decreased drainage.

(b) Dilatation of ocular vessels as in association with hypercarbia or hypoxia.

(c) Increased central venous pressure.

(d) Increased extra-ocular muscle tone.

On the other hand, factors operating in the opposite direction to these will result in a decrease in intra-ocular pressure.

The mechanism by which etomidate reduces the intra-ocular pressure has not been determined in this study. Systemic hypotension has been shown to cause a decrease in intra-ocular pressure ${ }^{9}$ but there was no hypotension associated with etomidate administration in these patients. A decrease in the tone of the extra-ocular muscles can result in a decrease in intra-ocular pressure, but such a decrease would not be expected to occur with etomidate, which is associated with some myoclonic movements. There was no clinically detectable respiratory depression which could have resulted in hypercarbia and hypoxia; but even if there was, the effect of hypercarbia and hypoxia would have been to increase rather than to decrease intra-ocular pressure.10.11 Whatever the mechanism of reduction of intra-ocular pressure may be, it is appropriate to use etomidate as an induction agent when elevation of intra-ocular pressure is undesirable.

\section{SUMmary}

Etomidate, a new short-acting non-barbiturate hypnotic, was administered to 40 patients between the ages of 12 years and 65 years. Intra-ocular pressure was measured before and after etomidate injection using a Schiotz tonometer. A significant reduction of intra-ocular pressure was found to follow etomidate injection in spite of the often associated myoclonic movements. The mechanism of reduction of intra-ocular pressure has not been determined in this study. It is suggested that etomidate will be a useful intravenous induction agent where elevation of intra-ocular pressure is undesirable.

\section{RÉSUMÉ}

La pression intra-oculaire a été mesurée qu moyen d'un tonomètre de Schiotz, avant et après administration d'Etomidate, un nouvel hypnotique non barbiturique. Quarante malades âgés de 12 à 65 ans ont été ainsi étudiés.

On a mis en évidence une réduction importante de la pression intra-oculaire à la suite de Padministration d'Etomidate, ceci malgré une incidence de 35 pour cent de mouvements myocloniques associés. Le mécanisme responsable de la réduction du tonus intra-oculaire n'a pas été étudié.

L'Etomidate semble un agent d'induction utile lorsque l'on veut éviter une élévation de la pression intra-oculaire.

\section{ACKNOWLEDGEMENT}

We wish to thank Prof. S.A. Oduntan for his support and useful suggestions during this study. Etomidate was supplied by Janssen Pharmaceutica. 


\section{REFERENCES}

1. Famewo, C.E. \& Odugbesan, C.O. Clinical trial of etomidate. Canad. Anaesth. Soc. J. 24: 35 (1977)

2. Gooding, J.M. \& Conssen, D.C. Etomidate: an ultrashort-acting non-barbiturate agent for anesthesia induction. Anesthesia and Analgesia: Current Researches 55: 148 (1976).

3. Konnblueth, W., Aladjemoff, L., Magora, A., \& Gabbay, A. Influence of general anaesthesia on intraocular pressure in man. Arch. of Ophthal. 61: 84 (1959).

4. Joshi, C. \& Bruce, C. Thiopentone and succinylcholine: action on intraocular pressure. Anesthesia and Analgesia 54: 471 (1975).

5. Macora, F. \& Collins, V.Z. Influence of general anaesthetic agents on intraocular pressure in man. The effect of common non-explosive agents. Arch, of Ophthal. 66: 806 (1962).

6. Ivankovic, A.D. \& Lowe, H.J. The influence of methoxyflurane and neurolept anesthesia on intraocular pressure in man. Anesthesia and Analgesia: Current Researches 48: 933 (1969).

7. Conssen, G. \& Hox, J.E. A new parenteral anesthetic 1-581. Its effect on intraocular pressure. Journal of Pediatric Ophthalmology 4: 20 (1967).

8. Al-Abrak, M.H. \& Samuel, J.R. Effect of general anaesthesia on intraocular pressure in man: trichloroethylene in nitrous oxide and oxygen. British Journal of Ophthalmology 59: 107 (1975).

9. AdAMs, A.K. \& Barnett, K.C. Anaesthesia and intraocular pressure. Anaesthesia 21: 202 (1966).

10. Beauvie, A. \& Samuel, J.R. Effect of $\mathrm{CO}_{2}$ on intraocular pressure in man during general anaesthesia. Brit. Jour. Anaes. 45: 119 (1973).

11. Duncalf, D. \& Weitznef, S.W. The influence of ventilation and hypercapnia on intraocular pressure during anesthesia. Anesthesia and Analgesia: Current Researches 42: 232 (1963). 